\title{
Mineral Resources of the Gila Lower Box Wilderness Study Area, Grant and Hidalgo Counties, New Mexico
}
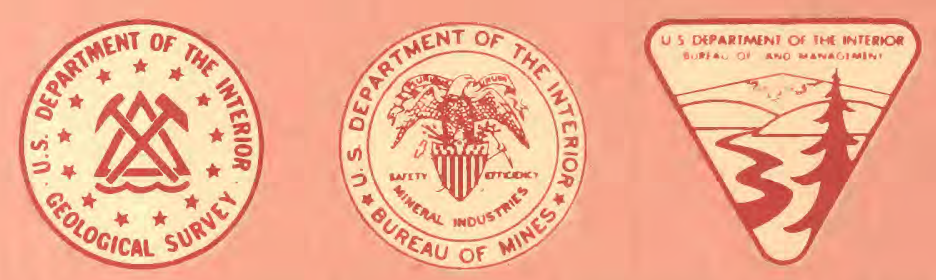

\section{U.S. GEOLOGICAL SURVEY BULLETIN 1735-A}

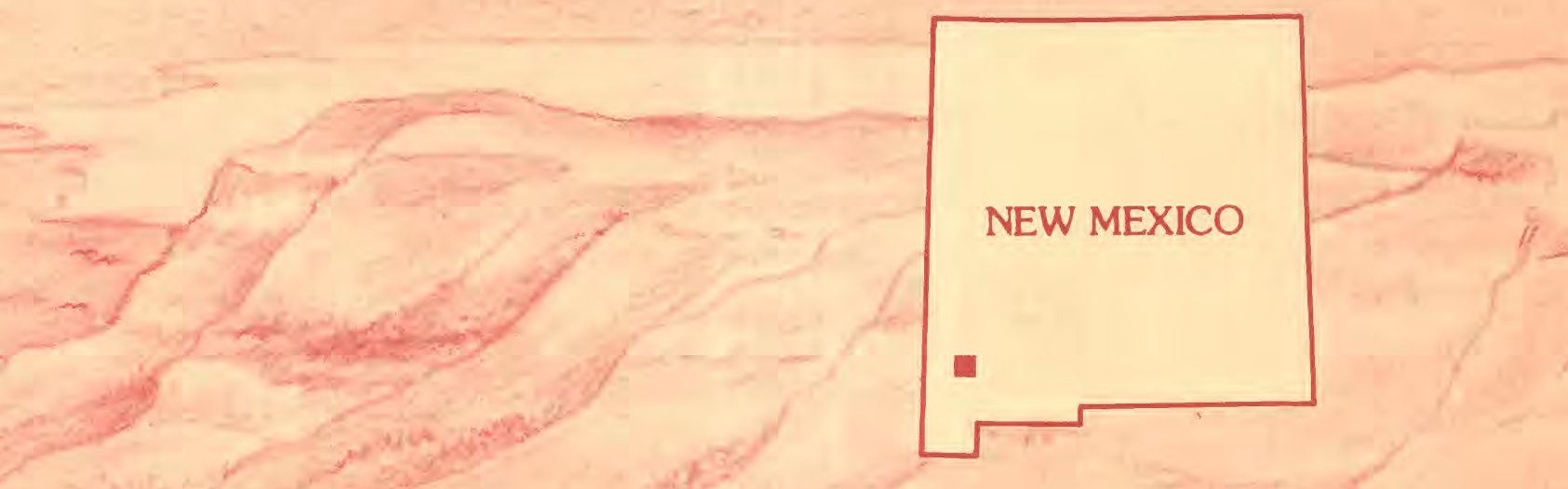



Chapter A
Mineral Resources of the
Gila Lower Box Wilderness Study Area, Grant and Hidalgo Counties, New Mexico

By DONALD H. RICHTER, VIKI A. LAWRENCE, HARLAN BARTON, WILLIAM HANNA, and JOSEPH S. DUVAL U.S. Geological Survey

GEORGE S. RYAN

U.S. Bureau of Mines

U.S. GEOLOGICAL SURVEY BULLETIN 1735

MINERAL RESOURCES OF WILDERNESS STUDY AREASSOUTHWESTERN NEW MEXICO 


\title{
DEPARTMENT OF THE INTERIOR DONALD PAUL HODEL, Secretary
}

\author{
U.S. GEOLOGICAL SURVEY
}

Dallas L. Peck, Director

For sale by the

Books and Open-File Reports Section

U.S. Geological Survey

Federal Center

Box 25425

Denver, CO 80225

\section{Library of Congress Cataloging-in-Publication Data}

Mineral resources of the Gila Lower Box Wilderness Study Area, Grant and Hidalgo Counties, New Mexico.

(Mineral resources of wilderness study areas-southwestern New Mexico ;

ch. A) (U.S. Geological Survey bulletin ; 1735)

Bibliography: $p$.

Supt. of Docs. no.: I 19.3:1735-A

1. Mines and mineral resources-New Mexico-Gila Lower Box Wilderness.

2. Gila Lower Box Wilderness (N.M.) I. Richter, Donald H. II. Series.

III. Series: U.S. Geological Survey bulletin ; 1735.

QE75.B9 no. 1735-A 557.3 s [557.89] 87-600388

[TN24.N6] 


\section{STUDIES RELATED TO WILDERNESS}

\section{Bureau of Land Management Wilderness Study Areas}

The Federal Land Policy and Management Act (Public Law 94-579, October 21, 1976) requires the U.S. Geological Survey and the U.S. Bureau of Mines to conduct mineral surveys on certain areas to determine the mineral values, if any, that may be present. Results must be made available to the public and be submitted to the President and the Congress. This report presents the results of a mineral survey of a part of the Gila Lower Box Wilderness Study Area (NM-030-023), Hidalgo and Grant Counties, New Mexico. 


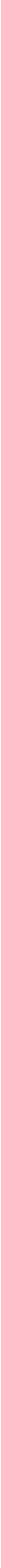




\section{CONTENTS}

Abstract A1

Summary A1

Introduction A2

Investigations by the U.S. Bureau of Mines

Investigations by the U.S. Geological Survey

Appraisal of identified resources A4

Mining and mineral exploration history

A4

Caprock mining district

A4

Mines, prospects, mining claims, and leases

Consolation mine $\mathbf{A 4}$

Black Bob prospect A4

Prospects within the study area A4

Mineral and energy occurrences A4

Sand and gravel

A4

Oil and gas

A4

Sand-casting tuff occurrence

Assessment of mineral resource potential

Geology

A5

Geochemistry

A5

Analytical methods

A5

Results

A8

Geophysics

A8

Gravity data

A8

Aeromagnetic data

Aerial gamma-ray data

Mineral and energy resources

References cited

A12

Appendix

A15

\section{FIGURES}

1-5. Maps of the Gila Lower Box Wilderness Study Area and vicinity showing:

1. Mineral resource potential and identified resources

A2

2. Location $\mathbf{A 3}$

3. Geology A6

4. Terrain-corrected Bouguer gravity anomaly contours

5. Filtered aeromagnetic anomaly contours

A11 


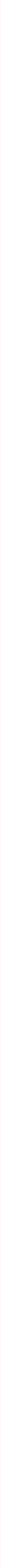




\title{
Mineral Resources of the Gila Lower Box Wilderness Study Area, Grant and Hidalgo Counties, New Mexico
}

\author{
By Donald H. Richter, Viki A. Lawrence, Harlan Barton, \\ William Hanna, and Joseph S. Duval \\ U.S. Geological Survey
}

George S. Ryan

U.S. Bureau of Mines

\begin{abstract}
The Gila Lower Box Wilderness Study Area (NM-030-023) is in Grant and Hidalgo Counties in southwestern New Mexico, 27 mi (miles) northwest of Lordsburg. Identified resources of manganese, which have been mined in the past, occur within $0.25 \mathrm{mi}$ of the study area boundary, but none are known within the study area. There are no other identified resources. The study area has (1) high mineral resource potential for manganese in its eastern part, (2) moderate mineral resource potential for manganese in its western part, and (3) low mineral and energy resource potential throughout for other metals, gemstone, geothermal energy, and oil and gas (fig. 1).
\end{abstract}

\section{SUMMARY}

The topography of the Gila Lower Box Wilderness Study Area (location map, fig. 2) is dominated by a 200- to 500 -ft-deep canyon cut into the layered Tertiary (see geologic time chart in Appendix) volcanic rocks by the Gila River. The area is accessible by improved and unimproved dirt roads.

The rocks in the study area consist of layered Tertiary volcanic rocks and associated volcaniclastic rocks with a total thickness of more than $2,500 \mathrm{ft}$ (feet). Some of the volcanic rocks are covered by younger alluvial deposits, but most bedrock exposures are good. Canador Peak, an andesitic dome, is the only known volcanic vent in the study area; the remainder of the volcanic rocks are from sources outside the study area. Geologic mapping outside the study area indicates that the volcanic sequence is underlain by sedimentary rocks of Cretaceous age that lie on Precambrian granite. Structurally, the area is tilted $5-20^{\circ}$ to the northeast along northwest-trending normal faults that have offsets of less than $500 \mathrm{ft}$. Faulting occurred during middle to late Tertiary time and is related to Basin and Range extension.

Identified resources of manganese are in shallow veins in the Caprock mining district (fig. 1), 2 mi to the southeast, as well as in veins only 0.25 mi east and north of the study area. The Caprock mining district produced 5,000 tons of manganese oxide in the 1950's. The ore is in discontinuous veins in volcanic conglomerate. The Consolation mine, 0.25 mi east of the study area, produced 10,000 tons of ore from a fault zone. The Black Bob prospect, 0.25 mi north of the study area, has had no known production, although the property has a 75-ft-deep shaft.

Material from a discontinuous tuff bed that crops out 0.5 mi northeast of the study area has been used by a local silversmith for sand casting. The tuff is not known to occur within the study area.

Sand and gravel deposits south of the study area have been used locally, but none have been mined in the study area.

A geochemical study found only one sample containing tin, barium, and chromium in anomalous amounts. Although this sample was collected within the study area, it actually represents sediment from a drainage largely outside the study area, and the anomalous values are assumed to represent rocks outside the study area.

Geophysical data do not indicate the presence of any mineral resources in the study area. However, the gravity data indicate the presence of a northwest-trending fault, related to Basin and Range deformation, in the southwest margin of the study area.

The Gila Lower Box Wilderness Study Area has a high mineral resource potential for manganese in its eastern part, and a moderate mineral resource potential for manganese in its western part, with certainty level $\mathrm{C}$, based on the presence of manganese vein deposits nearby, as well as the presence 


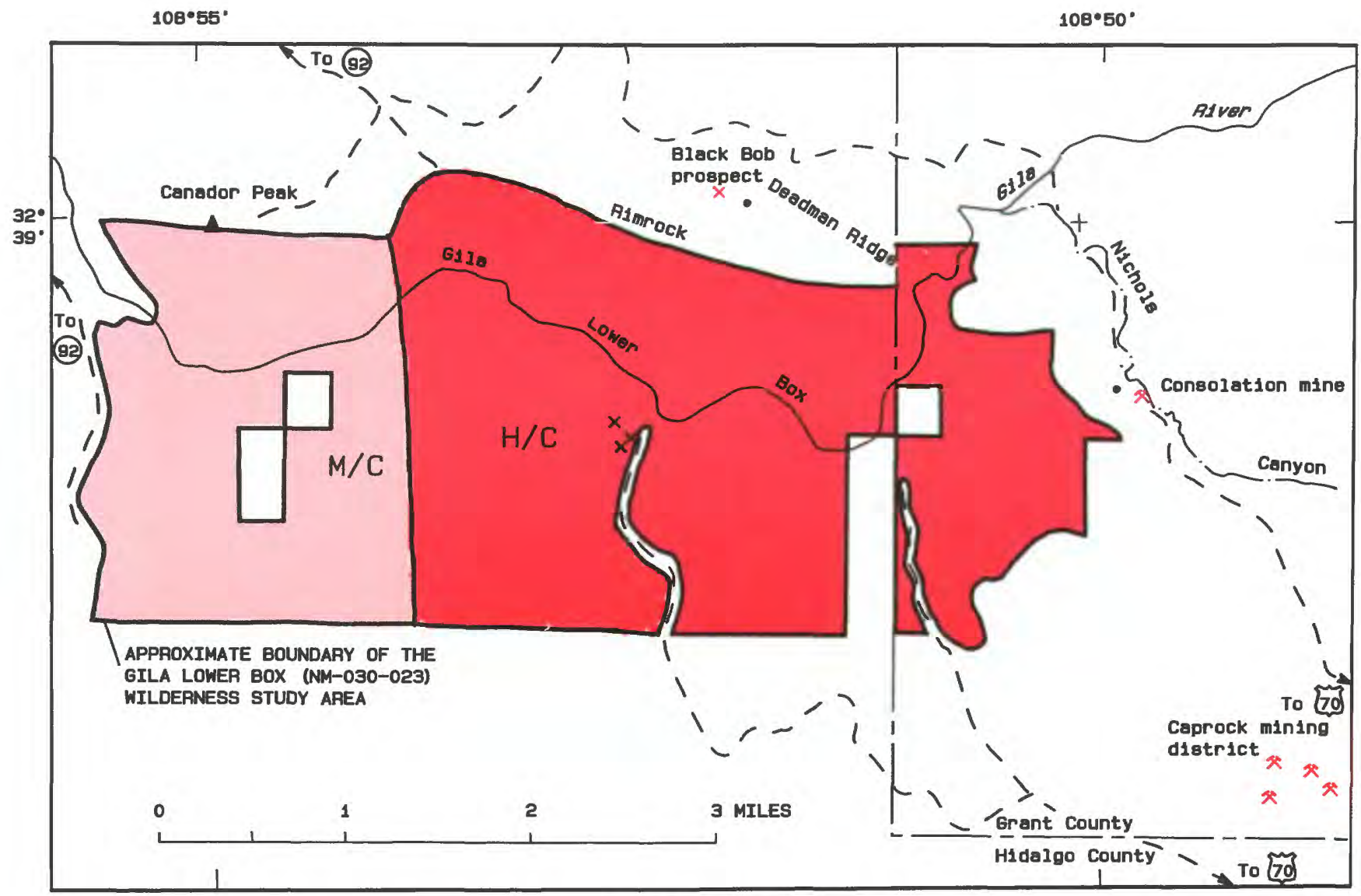

EXPLANATION

[Entire study area has a low mineral and energy resource potential for all metals (other than manganese), gemstone, geothermal energy, and oil and gas, with certainty level C]

\begin{tabular}{|c|c|c|c|}
\hline 3 & Identified resources & $\mathrm{C}$ & $\begin{array}{l}\text { Certainty level-Data indicate geologic environment } \\
\text { and resource potential but do not establish }\end{array}$ \\
\hline$x$ & Manganese-vein mine & & activity of resource-forming processes \\
\hline$x$ & Manganese-vein prospect & + & Sand-casting tuff occurrence \\
\hline $\mathrm{H} / \mathrm{C}$ & $\begin{array}{l}\text { Geologic terrane having high mineral resource potential for } \\
\text { manganese in vein deposits, with certainty level } \mathrm{C}\end{array}$ & $\bullet$ & USBM sampling locality \\
\hline $\mathrm{M} / \mathrm{C}$ & $\begin{array}{l}\text { Geologic terrane having moderate mineral resource potential } \\
\text { for manganese in vein deposits, with certainty level C }\end{array}$ & X & Prospect pit \\
\hline
\end{tabular}

Figure 1. Summary map showing mineral resource potential and identified resources of the Gila Lower Box Wilderness Study Area and vicinity, Grant and Hidalgo Counties, New Mexico.

of suitable structures and bedrock exposures especially in the eastern part of the study area. The mineral and energy resource potential is low for other metals, gemstone, geothermal energy, and oil and gas, with certainty level $C$.

\section{INTRODUCTION}

The USGS (U.S. Geological Survey) and the USBM (U.S. Bureau of Mines) studied 5,835 acres of the 8,555-acre Gila Lower Box Wilderness Study Area (NM-030-023) as requested by the BLM (U.S. Bureau of Land Management). In this report the studied area is referred to as the "wilderness study area" or simply the "study area."

The Gila Lower Box Wilderness Study Area is in Hidalgo and Grant Counties in southwestern New Mexico, approximately $27 \mathrm{mi}$ northwest of Lordsburg (fig. 2). Access to the study area south of the Gila River is provided by improved dirt roads that branch off U.S. Highway 70 about 13 and $19 \mathrm{mi}$ northwest of Lordsburg, and by an unimproved dirt road off New Mexico State Highway 92 just south of the Gila River bridge. Access to the study area north of the Gila River is more difficult but may be obtained by an unimproved dirt road that extends east from New Mexico State Highway 92 just 


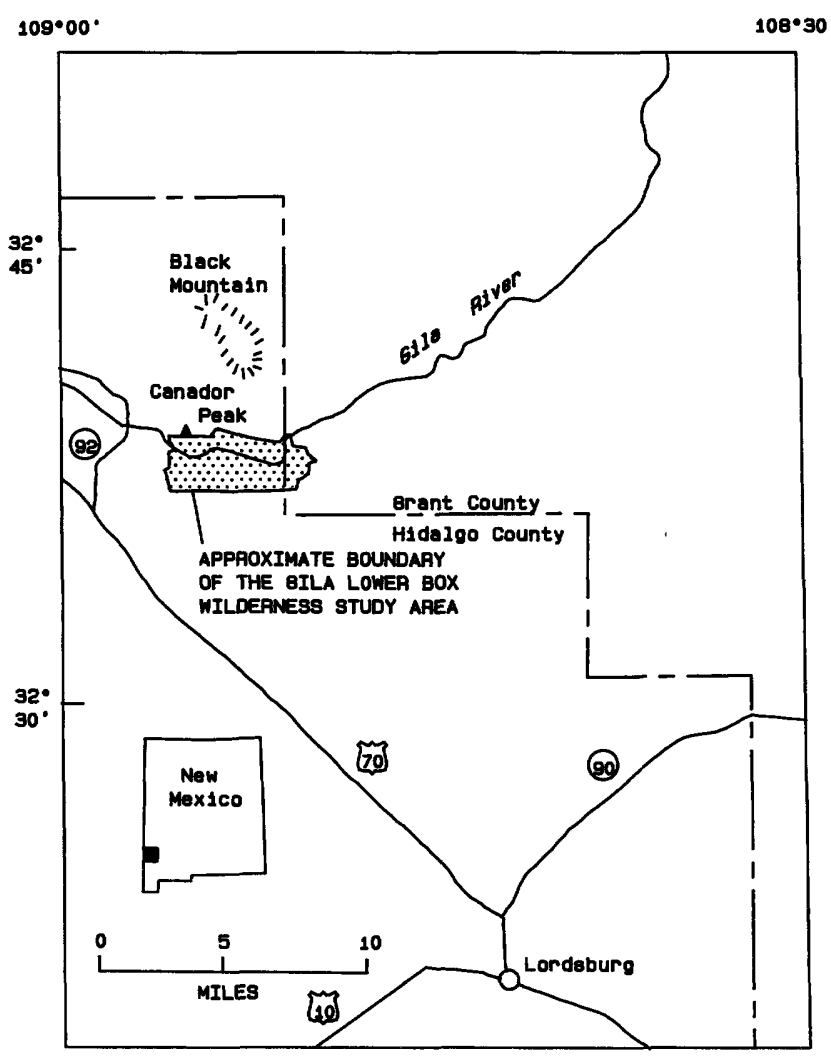

Figure 2. Map showing location of the Gila Lower Box Wilderness Study Area, Grant and Hidalgo Counties, New Mexico.

north of the Gila River bridge. All the dirt roads can be difficult to travel during and after periods of inclement weather.

The wilderness study area is on the south slope of the Mogollon volcanic highlands, a transition zone between the southern Basin and Range physiographic province to the south and the Colorado Plateau to the north. The area's main physiographic feature is a 200- to 500 -ft-deep canyon cut into layered volcanic rocks of Tertiary age (15-35 m.y. (million years) old) by the Gila River. Uplands south of the river are characterized by a gently north-dipping alluvial plain that is locally transected by small canyons and arroyos. A few low hills protrude above the alluvial surface. Elevations range from 4,500 $\mathrm{ft}$ above sea level on the slopes of Canador Peak to about $3,800 \mathrm{ft}$ where the Gila River flows out of the study area.

This report presents an evaluation of the mineral endowment (identified resources and mineral resource potential) of the Gila Lower Box Wilderness Study Area and is the product of several separate studies by the USBM and the USGS. Identified resources are classified according to the system of the USBM and USGS (1980), which is shown in the Appendix. Identified resources are studied by the USBM. Mineral resource potential is the likelihood of occurrence of undiscovered metals and nonmetals, industrial rocks and minerals, and of undiscovered energy sources (coal, oil, gas, oil shale, and geothermal sources). It is classified according to the system of Goudarzi (1984), which is shown in the Appendix. The potential for undiscovered resources is studied by the USGS.

\section{Investigations by the U.S. Bureau of Mines}

The USBM investigation included, in 1984, a review of published material relating to the mineral resources and mining activity in and near the study area. Claim status was checked in the BLM claim files. Four rock-chip and two grab samples were taken (fig. 1). All samples were analyzed for gold and silver by fire assay. Copper, manganese, molybdenum, lead, and zinc were determined by inductively coupled plasma-atomic emission spectrometry. Results are discussed by Ryan (1985).

\section{Investigations by the U.S. Geological Survey}

Field investigations consisted of about two weeks of geologic mapping in 1985, geochemical sampling, and examination of mines and prospects to help determine potential deposit types. Geologic studies were aided by previous mapping in the area (D.C. Hedlund and T.L. Finnell, unpub. mapping, 1979, Canador Peak 71/2' quadrangle, New Mexico). The lack of bedrock throughout large sections of the study area, especially south of the Gila River, together with the absence of locally derived alluvium rendered the geochemical investigation meaningless in a major part of the study area. Large-scale gravity and aeromagnetic maps of the wilderness study area and vicinity were prepared from gravity and magnetic data used in the USGS's mineral resource assessment of the Silver City $1^{\circ} \times 2^{\circ}$ quadrangle, New Mexico and Arizona (Wynn, 1981; Klein, 1987). No new geophysical data were acquired for this resource evaluation.

Acknowledgments.-Personnel of the BLM in Las Cruces, N. Mex., were extremely helpful in providing background information on the wilderness study area. Thanks are also due James C. Ratté, USGS, and William C. McIntosh, a graduate student at New Mexico Institute of Mines and Technology, who accompanied D.H. Richter during the geologic investigations of the area and provided pertinent observations regarding some of the geology. 
APPRAISAL OF IDENTIFIED RESOURCES

\section{By George S. Ryan \\ U.S. Bureau of Mines}

\section{Mining and Mineral Exploration History}

Shallow manganese occurrences associated with hot-spring transportation and concentration are found in faults near the study area (Elston, 1960). Hot-spring deposits of opal and travertine, and minor amounts of manganese, are found in prospect pits within the study area (fig. 1), but none are economic.

No mines or claims are in the study area, but manganese was produced from mines within $0.25-2 \mathrm{mi}$ of the study area boundary. All of the producing manganese zones are shallow, the deepest being $70 \mathrm{ft}$ in the Caprock mining district (Gillerman, 1964). Secondary enrichment associated with hot-springs activity concentrated the manganese minerals (Elston, 1960). The low-grade manganese ore produced was upgraded by jigging to concentrates of 43 percent manganese oxide before shipping (Gillerman, 1964).

\section{Caprock Mining District}

The Caprock mining district, 2 mi southeast of the study area (fig. 1), produced 5,000 tons of manganese oxide from near-surface deposits in the 1950 's, and is considered to have identified manganese resources. Ore minerals were mainly psilomelane and minor pyrolusite (Gillerman, 1964). The ore is in discontinuous sections of small fractures within a volcanic conglomerate.

\section{Mines, Prospects, Mining Claims, and Leases}

The Consolation mine, east of the study area, was sampled and the various workings in the Caprock mining district, southeast of the study area, were examined during this survey. The Black Bob prospect, north of the study area, was also sampled. Both the Consolation mine and the Black Bob prospect are considered to have identified manganese resources. A cluster of small prospect pits and trenches within the study area were examined and 3 samples were taken (fig. 1).

\section{Consolation Mine}

During the 1950 's, about 10,000 tons of ore assaying 8-10 percent manganese was produced from the Consolation mine, $1 / 4 \mathrm{mi}$ east of the study area. The ore was produced from an 8- to 14-ft-thick fault zone over a
N. $45^{\circ}$ W. strike length of $120 \mathrm{ft}$ (Gillerman, 1964). At the surface the footwall is a well-defined, 50-ft-high, nearvertical cliff in basaltic andesite. The hanging wall is in the Gila Conglomerate (Miocene to Pleistocene). Two samples taken at the north face of the surface stope assayed 5.6 percent manganese on the footwall part of the vein and 1.3 percent manganese on the hanging wall part. Discontinuous calcite and quartz veinlets within the mineralized zone are characteristic of the veins in the area. The Consolation mine vein does not project into the study area.

\section{Black Bob Prospect}

The Black Bob prospect is $0.25 \mathrm{mi}$ north of the study area (fig. 1) in a thick unit of andesite flows. A 75-ft-deep shaft inclined $78^{\circ} \mathrm{SW}$., which was inaccessible at the time of this study, once provided entry to a 12 -ft-wide east-striking zone of argillized brecciated basalt and gouge containing disseminated psilomelane (Gillerman, 1964). A sample, taken from altered gouge near the top of the shaft, assayed less than 0.1 percent manganese. The extent of underground workings is not known nor is there any record of production. The east trend of the brecciated basalt zone parallels the northern boundary of the study area.

\section{Prospects Within the Study Area}

Several small pits and trenches in calcite- and quartz-bearing outcrops are found near the north end of the westernmost road within the study area (fig. 1). Two samples were collected at three of the pits; the highest manganese assay from these samples was 0.44 percent; no resources were identified. Joint planes and minor fractures were locally coated with quartz and calcite. The host rock is a volcanic conglomerate, the same as in the Caprock mining district.

\section{Mineral and Energy Occurrences}

\section{Sand and Gravel}

Unconsolidated terrace gravels are widely distributed south of the study area and have been a major local source of sand and gravel. The limited exposures of similar terrace gravels within the southern part of the study area are not readily accessible and therefore not likely to be developed.

\section{Oil and Gas}

No oil or gas wells have been drilled in the study area or in the immediate vicinity, and there are no oil and gas leases in the study area. 


\section{Sand-Casting Tuff Occurrence}

A thin, discontinuous, ash-flow tuff (included in the Gila Conglomerate, unit QTg, fig. 3) crops out in Nichols Canyon, $0.5 \mathrm{mi}$ northeast of the study area, and has been used by a local silversmith for sand casting (T.L. Finnell, USGS, oral commun., 1987). Prior to using this tuff the artist paid $\$ 2 / \mathrm{lb}$ in 1979 for a similar material. The tuff bed is about $1.5 \mathrm{ft}$ thick and has a fairly small known outcrop area. There are no known outcrops of the tuff in the study area.

\section{ASSESSMENT OF MINERAL RESOURCE POTENTIAL}

\section{By Donald H. Richter, Viki A. Lawrence, Harlan Barton, William Hanna, and Joseph S. Duval \\ U.S. Geological Survey}

\section{Geology}

The wilderness study area is along the southern margin of the Mogollon volcanic highlands, a very large and complex Tertiary volcanic province in New Mexico and Arizona. The area also lies at the north end of the Burro Mountains arch (Stacey and Hedlund, 1983), a structurally positive element during late Precambrian, Paleozoic, and most of Mesozoic time.

A sequence of layered volcanic rocks and associated volcaniclastic rocks of middle Tertiary age underlies most of the wilderness study area (fig. 3). Bedrock exposures are generally good except for some of the highlands south of the Gila River, which are locally covered by younger alluvial deposits. The layered volcanic and volcaniclastic rock sequence totals more than 2,500 ft thick. From oldest to youngest, it consists of (1) a 33-m.y.-old ash-flow tuff, (2) volcaniclastic rocks derived from an andesitic terrain, (3) two 28- to 30-m.y.old ash-flow tuffs-Oligocene Bloodgood Canyon Tuff and the tuff of Fall Canyon, (4) a series of andesitic to basaltic lava flows, which in part are as young as 21 m.y., and (5) a thick unit of conglomerate and coarse sandstone, the Gila Conglomerate, that was largely deposited after the cessation of eruptive volcanic activity. The base of this layered volcanic sequence is only observed locally on Canador Peak where it unconformably overlies a 35-m.y.-old andesite dome.

None of the volcanic rocks in the layered sequence appear to have been erupted from vents in or near the wilderness study area. The older ash-flow tuff is probably a caldera-related tuff from the Cliff eruptive center, 20 mi to the northeast (Drewes and others, 1985). Both the
Bloodgood Canyon Tuff and the tuff of Fall Canyon are regional ash-flow tuff sheets (Ratté and others, 1984). The Bloodgood Canyon Tuff is related to the collapse of the Bursum caldera, $45 \mathrm{mi}$ to the north; the tuff of Fall Canyon is from an undetermined location. The andesitic to basaltic lava flows were probably erupted from linear rift zones to the north of the study area. The andesitic dome of Canador Peak is the only volcanic vent known to occur in the study area. However, geologic and geochemical evidence suggests that this center is an unfavorable environment for ore deposition.

The volcanic rocks of the wilderness study area have high-potassium calc-alkaline affinities, typical of the rocks throughout the eastern margin of the Western United States orogenic belt (Ewart, 1979). They were erupted during extensional tectonism in the middle and late Tertiary in response to plate interactions along the western margin of the orogen.

No Paleozoic rocks are known to be present in the section underlying the wilderness study area. Based on geologic studies beyond the boundaries of the wilderness study area (D. C. Hedlund and T. L. Finnell, unpub. mapping, 1979), the Upper Cretaceous Virden Formation of Elston (1960), as thick as $1,800 \mathrm{ft}$, overlies a thicker section of Cretaceous marine and nonmarine rocks, including the Upper(?) Cretaceous Beartooth Quartzite and the Upper Cretaceous Colorado Formation, which were deposited directly on a Precambrian granitic terrain. The middle Tertiary volcanic and volcaniclastic rocks of the area overlie, at relatively shallow depths, nonmarine shale, sandstone, and pebble conglomerate of the Virden Formation.

Structures in the wilderness study area and surrounding region do not appear to be complex. The layered volcanic rocks are tilted $5-20^{\circ}$ to the northeast along a series of northwest-trending, steeply dipping normal faults, with maximum offsets on individual faults probably less than $500 \mathrm{ft}$. The faults are mostly middle to late Tertiary in age, are related to Basin and Range extension, and some may reflect older pre-Tertiary structures.

\section{Geochemistry}

\section{Analytical Methods}

A reconnaissance geochemical survey was conducted in April 1985. Heavy-mineral concentrates derived from stream sediments were selected as the primary sample medium. The removal of most of the rock-forming silicates, clays, and organic material permits the determination of elements not generally detectable in bulk stream sediments by the analysis methods available. Some of these elements can be 




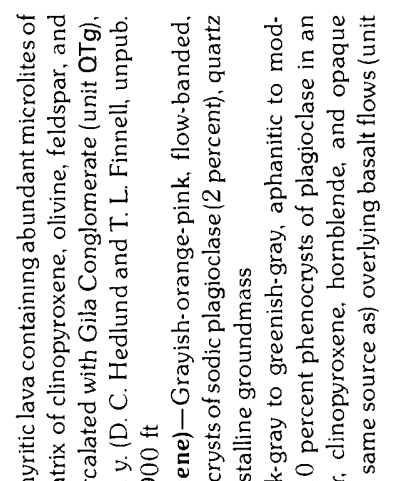

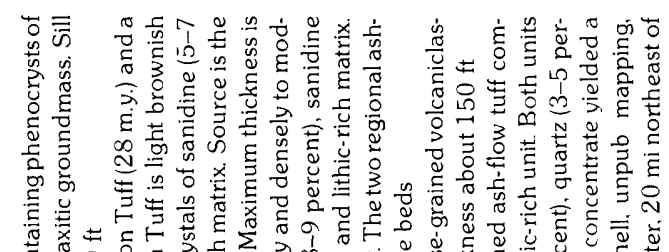

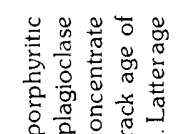

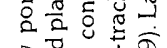

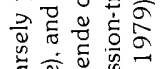

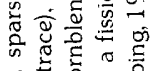

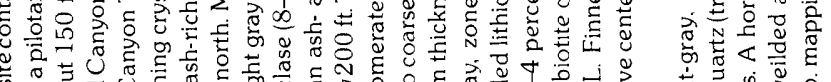

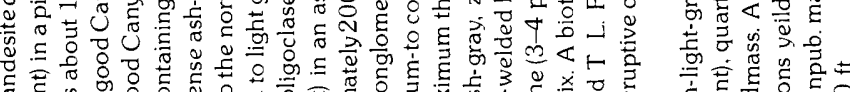
$\begin{array}{lll} & \\ 0 & & \\ 0\end{array}$

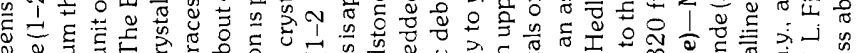

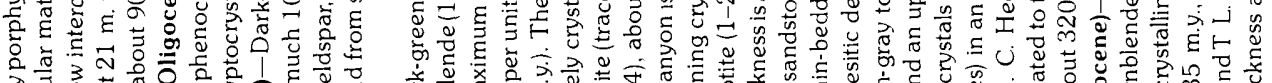

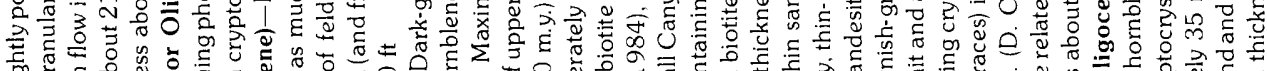

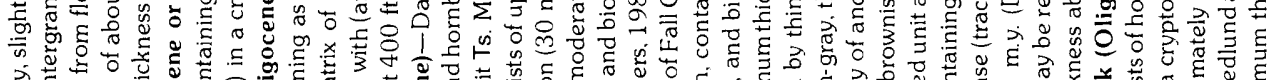

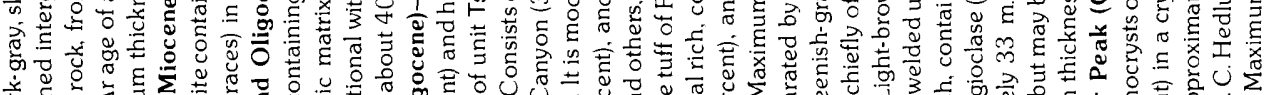

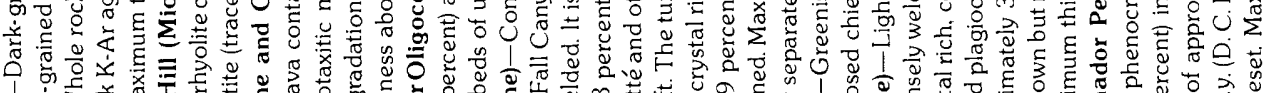

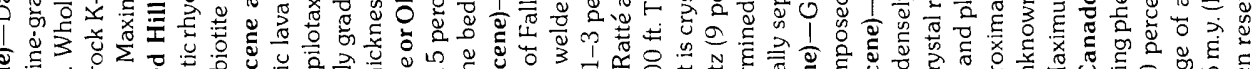

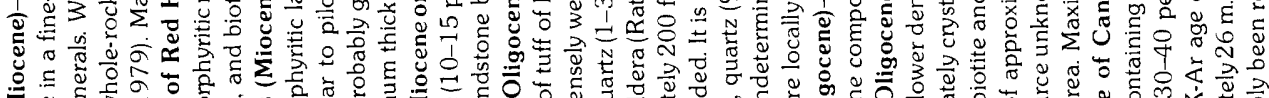

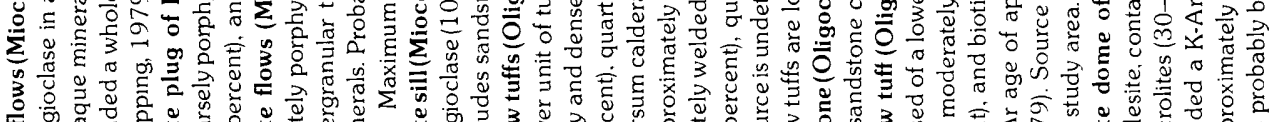

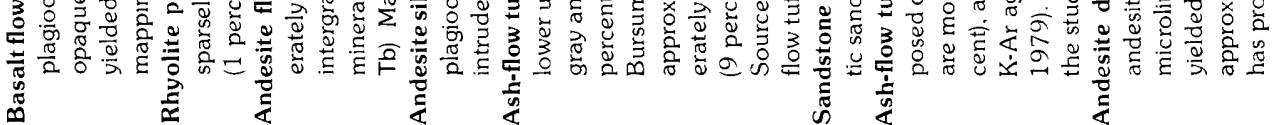

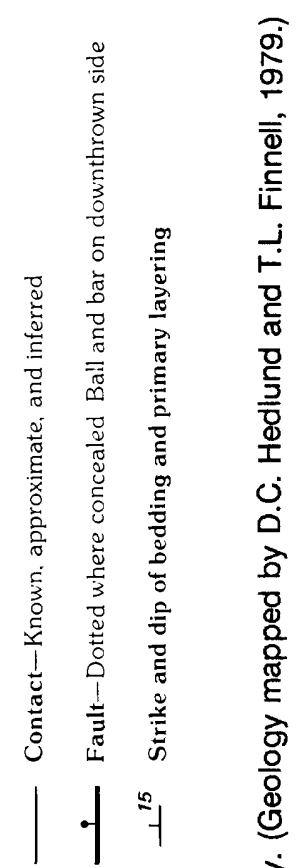

西

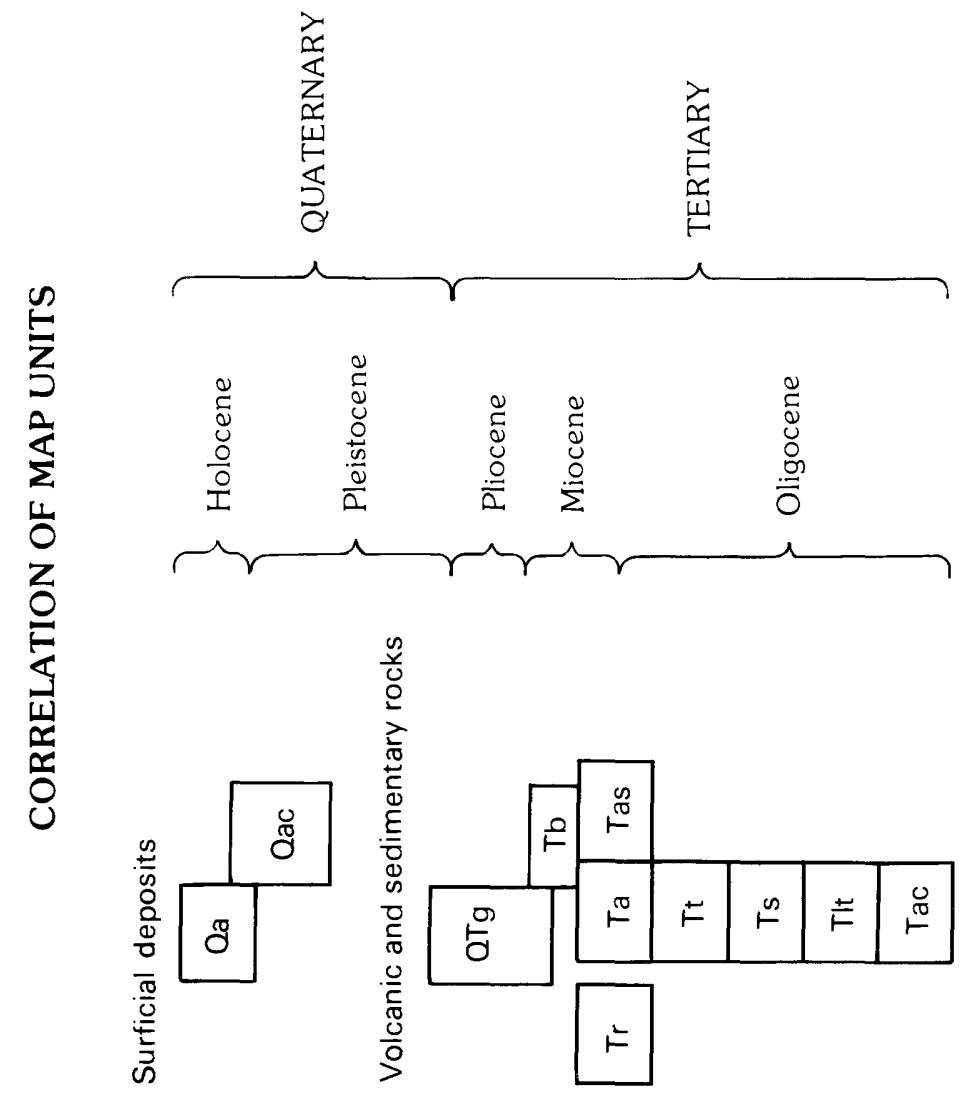

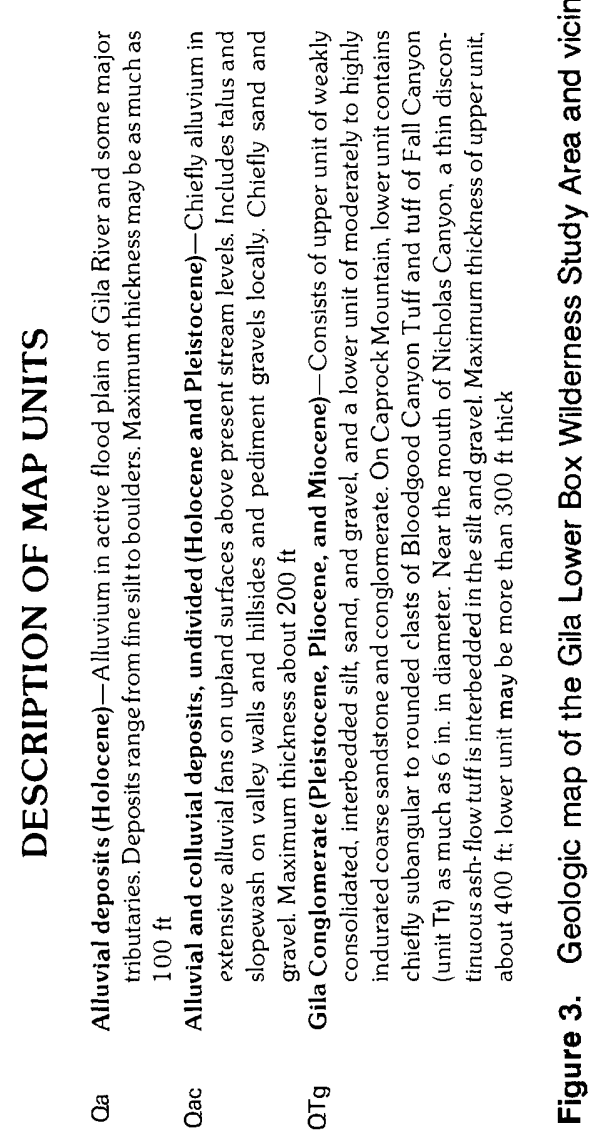


constituents of minerals related to ore-forming processes rather than rock-forming ones. These minerals include sulfide and oxide minerals such as pyrite $\left(\mathrm{FeS}_{2}\right)$, galena $(\mathrm{PbS})$, cassiterite $\left(\mathrm{SnO}_{2}\right)$, sphalerite $(\mathrm{ZnS})$, chalcopyrite $\left(\mathrm{CuFeS}_{2}\right)$, stibnite $\left(\mathrm{Sb}_{2} \mathrm{~S}_{3}\right)$, and cinnabar $(\mathrm{HgS})$. Other minerals concentrated in this medium are gold ( $\mathrm{Au})$, barite $\left(\mathrm{BaSO}_{4}\right)$, and scheelite $\left(\mathrm{CaWO}_{4}\right)$.

Fresh rocks were analyzed to provide background geochemical information. Altered and mineralized rocks from the vicinity of the Consolation mine were analyzed to provide information about the geochemical signature of the mineralizing system. Analytical data, sample sites, and a description of the geochemical sampling and analytical techniques are given in Barton and Day (1987).

Heavy-mineral-concentrate samples were collected at 19 sites from active alluvium in first-order and secondorder streams. Samples were composited across the stream channel. Rock samples were collected from three sites.

To produce the heavy-mineral concentrate, bulk stream sediment was sieved through a 10-mesh (2.0-mm) screen. Approximately 10 pounds of the minus-10-mesh sediment was panned to remove most of the quartz, feldspar, organic materials, and clay-sized material. The panned concentrate was separated into light and heavy fractions using bromoform (heavy liquid, specific gravity 2.8 ). The light fraction was discarded. The material of specific gravity greater than 2.8 was separated further into three fractions (highly magnetic, weakly magnetic, and nonmagnetic) using a modified Frantz ${ }^{1}$ Isodynamic Separator. The nonmagnetic fraction was hand ground and saved for analysis.

Rock samples were crushed and then pulverized to minus $0.15 \mathrm{~mm}$ with ceramic plates prior to analysis.

The heavy-mineral-concentrate and rock samples were analyzed for 31 elements using a semiquantitative, direct-current arc-emission spectrographic method (Grimes and Marranzino, 1968).

\section{Results}

One heavy-mineral-concentrate sample was determined to contain anomalous tin (2,000 ppm (parts per million)), barium (5,000 ppm), and chromium (500 $\mathrm{ppm}$ ). The sample was from the major drainage flowing south between Canador Peak and Rimrock, a drainage from an area mostly outside of the study area extending $2.5 \mathrm{mi}$ north to the southern slopes of Black Mountain. It was sampled within the study area, near the confluence with the Gila River, $1.2 \mathrm{mi}$ southeast of Canador Peak.

\footnotetext{
${ }^{1}$ Any use of trade names in this report does not constitute endorsement by the USGS.
}

The anomaly probably reflects the lithology of the Bloodgood Canyon Tuff and the tuff of Fall Canyon, which are exposed in the drainage basin on the slopes of Rimrock. No alteration or mineralization was observed in the study area, nor are there any exposures of the high-silica rhyolite associated with the Bursum caldera to the north, which contains high concentrations of tin as cassiterite (Ratté and others, 1984). No occurrence of mafic or ultramafic intrusive bodies are known as a source of the chromium.

\section{Geophysics}

The Gila Lower Box study area and vicinity (lat $32^{\circ} 35^{\prime}$ to $32^{\circ} 40^{\prime} \mathrm{N}$., long $108^{\circ} 49^{\prime}$ to $108^{\circ} 57^{\prime} \mathrm{W}$.) are covered by regional gravity and detailed aeromagnetic surveys having sufficient resolution to define anomalies of one-third square mile or more in areal extent. Gravity data are in the form of a terrain-corrected Bouguer gravity anomaly map (Wynn, 1981), based largely on about 20 stations within or adjacent to the area of figure 4. The geologic significance of the gravity map must be partly based on the relationships of anomalies to known source rocks outside of the map area. These relationships were studied by using the filtered aeromagnetic anomaly map of Klein (1983) and the areally extensive compilation of Cordell and others (1982). Aeromagnetic data are in the form of a filtered anomaly map (Klein, 1983), based largely on measurements made along 21 east-west flight lines spaced $0.6 \mathrm{mi}$ apart, at an average altitude of 1,500 ft above ground. Knowledge of rock density and magnetization (average dipole moment per unit volume) of units within the map area is based largely on measurements made in nearby areas (Bath, 1976; Klein and Johnson, 1983; Klein and Wynn, 1984), supplemented by a few measurements of the authors.

\section{Gravity Data}

The gravity data show four significant features in or near the area of figure 4, two highs and two lows, parts of which extend into the study area. A high centered northwest of the map area is inferred to be caused principally by Precambrian granitic rocks, which are known to have densities much higher than the average density of Tertiary volcanic rocks (Klein and Wynn, 1984). The high flattens southward for a distance of $4 \mathrm{mi}$ over a region underlain by tuffs and flows, which are extensively covered by Quaternary deposits, and finally noses out over the andesite dome of Canador Peak. The source of this flattened part of the high and its southpointing nose is ambiguous. The feature may express a southward continuation of Precambrian granitic rocks at increasingly greater depth in the study area, but it is 


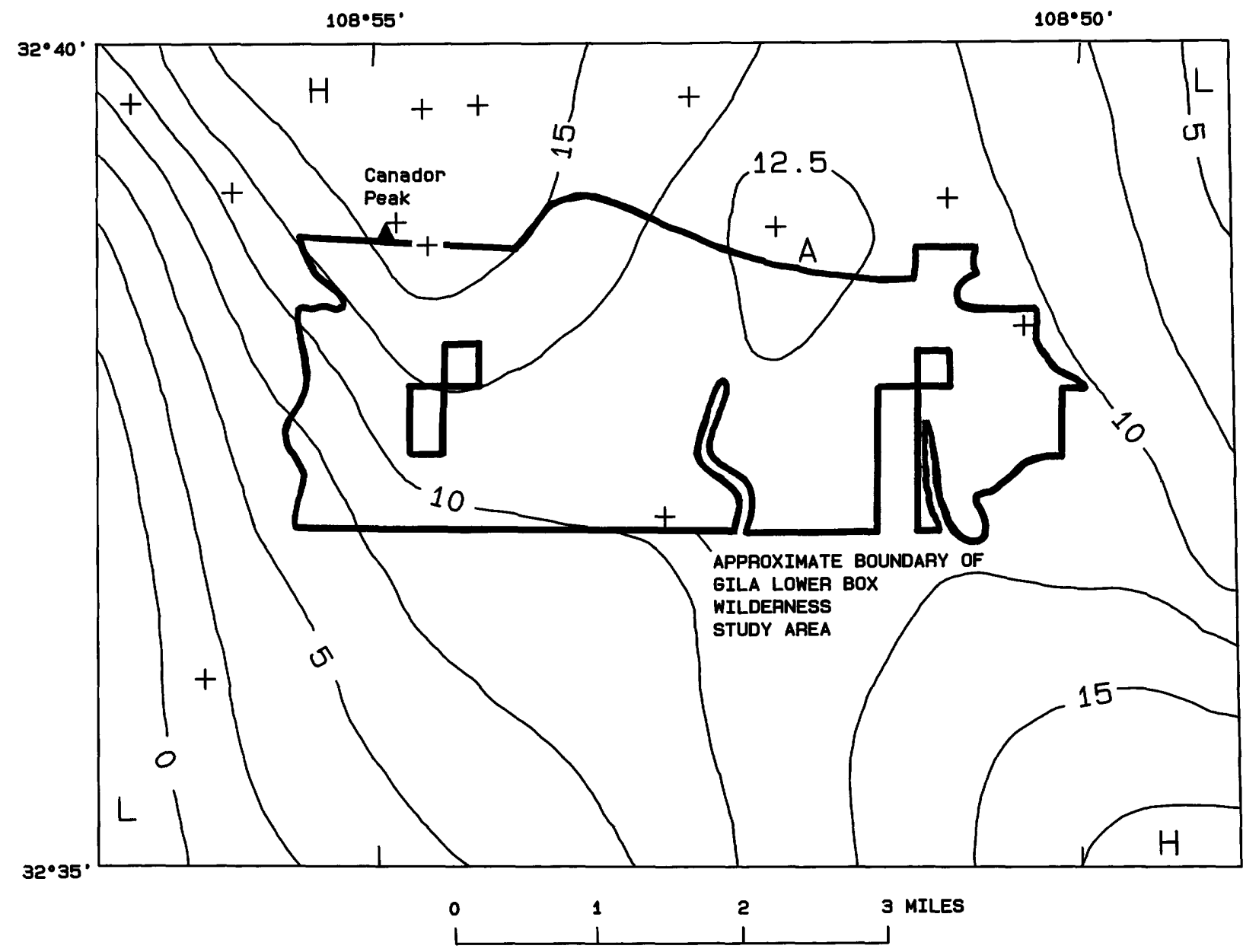

EXPLANATION

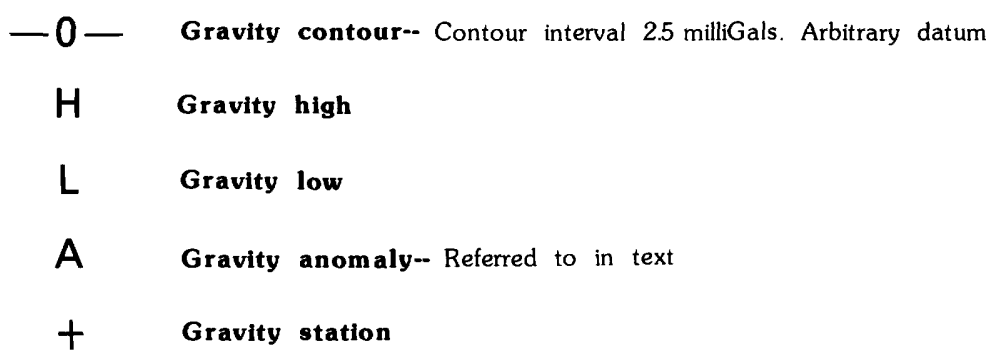

Figure 4. Terrain-corrected Bouguer gravity anomaly map of the Gila Lower Box Wilderness Study Area and vicinity. (Data from Wynn, 1981.)

probably caused in part by intermediate volcanic rocks, such as the andesite, having densities higher than Tertiary volcanic rocks and adjacent Quaternary deposits.

In the southeastern corner of the map area, a small part of another high trends northwest over limited outcrops of volcanic rocks extensively covered by Quaternary deposits. Because this high extends north- westward to within a mile or two of the study area, its source is of interest. Gravity data outside of the map area (Klein, 1983) show that the high links with two other highs, one associated with an isolated exposure of Precambrian granitic rocks and the other with a larger complex of Mesozoic intrusive and volcanic rocks, about 5 and 9 mi south-southeast of the southeastern corner of the map area, respectively. These associations of 
anomaly to exposed rock imply that the hidden source within the map area is Precambrian granitic rocks, Mesozoic intrusive and volcanic rocks, or both.

A major low partly shown in the southwestern corner of the map area is associated with low-density basin-fill and alluvial deposits, which are inferred to reach their maximum thickness about $3 \mathrm{mi}$ west of the southwestern corner of the map area. The steep, nearly linear gradient of the anomaly suggests the presence of a vertical fault presumed to be related to Basin and Range deformation and having a northwest-trending trace near the southwestern margin of the study area.

In the northeastern part of the map area, a low is part of another regional low associated with basin-fill and alluvial deposits, which are inferred to gradually increase in thickness southeast of the southeast corner of the map area. This feature may also be caused by a northwesttrending Basin and Range fault, but its occurrence and definition is less certain.

The four major gravity anomalies converge over a region including most of the study area, forming a saddle punctuated by a single contour closure marking a weak residual high ( $A$ on fig. 4). Anomaly gradients within the study area are generally low, with no manifestation that specific volcanic rock units are appreciably lower or higher on average than others. The exception previously noted is that the andesite of Canador Peak appears to be a little denser than most of its neighboring volcanic rocks in the subsurface.

\section{Aeromagnetic Data}

Major long-wavelength magnetic anomalies are seen most clearly by using a filtered version of the aeromagnetic anomaly map (Klein, 1983, 1987), simulating regional features that would have been mapped had the aircraft flown higher at a constant elevation of $1 \frac{1 / 4}{\mathrm{mi}}$. Figure 5 illustrates that the northern part of the map area is magnetically high and that the southern part is magnetically low, except for a high in the extreme southeast corner of the map area.

The broad low band traversing the southern part of the map area covers most of the study area. The low gradient is likely due to increasing depths of basin fill to the southwest away from the volcanic terrane.

In the extreme southeast corner of the map area, a small part of a weak magnetic high is of interest because its subsurface source may extend northwestward to within a mile or two of the southeast margin of the study area. This high correlates with the regional gravity high previously discussed. Nine miles to the south-southeast of the study area, associations of paired magnetic and gravity highs with exposed rocks suggest that the buried saurce is likely to be magnetic Laramide intrusive and volcanic rocks.
Based on criteria developed by Richter and others (1986), the geophysical data are more useful for defining broad terranes of mineral resource interest than for delineating mineral occurrences in specifically targeted areas. For example, manganese vein deposits and goldsilver-base metal vein deposits characteristically occur along or near northwest-trending faults cutting Tertiary volcanic and related intrusive rocks. The geophysical data suggest the subsurface occurrence of one such fault, inferred to cut across the southwest corner of the map area a few miles west of the study area. However, the volcanic rocks, known to host such vein deposits, are not identifiable because of the overprinting generated by basalt and andesite. The basalt, because of its diverse magnetic character, seems generally to be more of a hindrance than help in using magnetic anomaly data for assessment purposes. The geophysical data, to within the limits that they can be interpreted, do not signal the occurrence of a subsurface terrane beneath the study area itself likely to contain mineral deposits.

\section{Aerial Gamma-Ray Data}

Aerial gamma-ray spectroscopy is a technique that provides estimates of the near-surface (0-20 in. (inch) depth) concentrations of percent potassium (K), parts per million equivalent uranium (eU), and parts per million equivalent thorium (eTh). Because the uranium and thorium measurements utilize radioactive daughter nuclei that are chemically distinct from the parent nuclei, the uranium and thorium data are described as equivalent concentrations. These data $(\mathrm{K}, \mathrm{eU}, \mathrm{eTh})$ provide us with a partial geochemical representation of the near-surface materials. For a typical aerial survey each measurement reflects average concentrations for a surface area on the order of 15 square acres to an average depth of about 15 in.

From 1975 to 1983, the U.S. Department of Energy contracted for aerial gamma-ray surveys that covered almost all of the conterminous United States and much of Alaska. The flight-line spacings of these surveys vary from $1 \mathrm{mi}$ (rare) to $10 \mathrm{mi}$ and are, in general, only suitable for producing regional maps.

As part of a State mapping project, the data for New Mexico were compiled and processed to produce a series of 1:1,000,000-scale maps. These maps include the composite-color maps described by Duval (1983). These maps were examined to estimate the $\mathrm{K}$, eU, and $\mathrm{eTh}$ concentrations for the wilderness study area, and the occurrence or absence of anomalous radioelement concentrations were noted. The definition of an anomaly, as used in this report, requires that the element concentration as well as its ratios to the other two elements all be high values in the context of the map. 


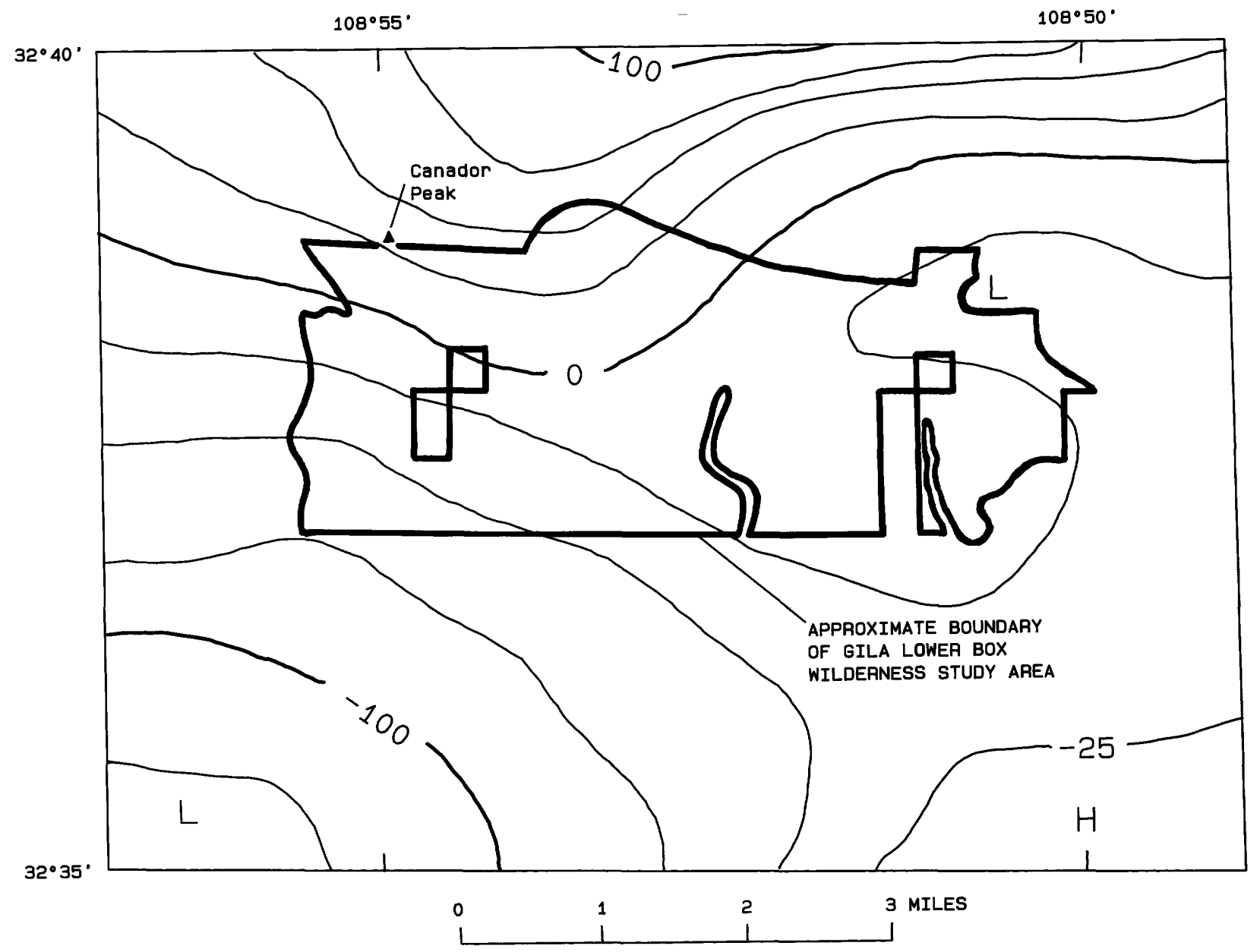

EXPLANATION

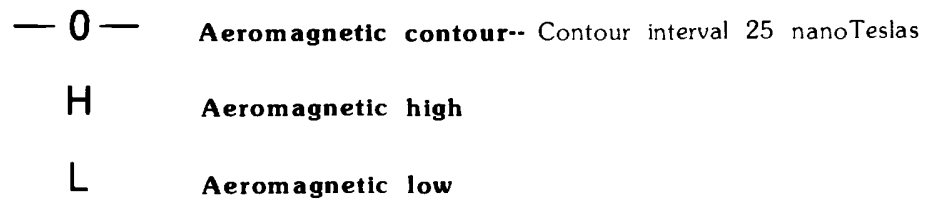

Figure 5. Filtered aeromagnetic anomaly map of the Gila Lower Box Wilderness Study Area and vicinity. (Data from Klein, 1987.) Original data have been processed to show anomalies having horizontal dimensions greater than about $2 \mathrm{~km}$.

The Gila Lower Box Wilderness Study Area has overall moderate radioactivity, with concentrations of 2.3-3.0 percent $\mathrm{K}, 2.3-2.5 \mathrm{ppm} \mathrm{eU}$, and 9-11 ppm eTh. There are no anomalies within or near the study area.

\section{Mineral and Energy Resources}

The mineral resource potential for manganese in the Gila Lower Box Wilderness Study Area is high in its eastern part and moderate in its western part, with certainty level $\mathrm{C}$. The study area has a low mineral and energy resource potential for all other metals, gemstone, geothermal energy, and oil and gas, with certainty level C. This statement is based on our available knowledge, as of September 1, 1987, of the surface and subsurface geology of the area and its environs.

The middle Tertiary high-potassium calc-alkaline volcanic terrane of the western orogenic belt in southwestern New Mexico and southeastern Arizona provides a favorable geologic environment for a restricted variety of ore deposit types, namely: granite- 
type molybdenum porphyry deposits, rhyolite-hosted tin deposits, epithermal manganese and fluorite veins, and some base-metal (copper, lead, zinc) and precious-metal (gold, silver) veins (Richter and others, 1986). Only the manganese vein deposits are expected to occur in the study area. These shallow, low-temperature deposits of manganese oxides and associated calcite and quartz are fissure fillings along fractures and minor faults, generally near larger faults. The presence of manganese vein deposits within 0.25 to $2 \mathrm{mi}$ north, east, and southeast of the wilderness study area and the presence of favorable host rocks (volcanic rocks) and structures (faults) within the study area indicate (1) a high mineral resource potential for these deposits, with certainty level $\mathrm{C}$, in the eastern part of the study area, where faults are present and bedrock is exposed, and (2) a moderate mineral resource potential for these deposits, with certainty level $\mathrm{C}$, in the western part of the study area, where faults and bedrock exposures are less common. The mineral resource potential for all other metals in the study area is low, with certainty level C.

Gemstone material is found locally throughout the study area, but is more a mineralogical curiosity than a resource. Agate and chalcedony commonly fill vesicles and fractures in the andesitic to basaltic lava flows, and banded calcite (travertine) is present locally in small veins and fractures. The three shallow prospect pits at the end of an unimproved road (fig. 1) expose some banded calcite veins; however, the pits were probably dug in search of manganese. The study area has a low mineral resource potential for gemstone, with certainty level C.

Although there are numerous hot springs within 50 mi of the study area and the Clifton Known Geothermal Resource Area is about $30 \mathrm{mi}$ to the northwest, there are no known hot springs in the immediate vicinity of the study area and the area is not considered to have any significant geothermal potential (Muffler, 1979). Therefore the energy resource potential for geothermal energy is low, with certainty level $\mathrm{C}$.

The energy resource potential for oil and gas in the wilderness study area is low (Ryder, 1982), with certainty level C. The study area, on the Burro Mountains arch, is not underlain by any measurable section of Paleozoic carbonate rocks that elsewhere in New Mexico are highly productive reservoir and source rocks. Subsurface Cretaceous rocks in the study area could conceivably have reservoir qualities, but their shallow depth beneath the Tertiary volcanic sequence and thinness of section are not favorable. No oil or gas wells have been drilled in the wilderness study area or general vicinity.

\section{REFERENCES CITED}

Barton, H.N., and Day, G.W., 1987, Analytical results and sample locality map of heavy-mineral-concentrate samples from the Lower Gila Box Wilderness Study Area
(NM-030-023), Grant and Hidalgo Counties, New Mexico: U.S. Geological Survey Open-File Report 87-294.

Bath, G.D., 1976, Interpretation of magnetic surveys in intermontane valleys of Nevada and southern New Mexico: U.S. Geological Survey Open-File Report 76-440, 37 p.

Cordell, L.E., Keller, G.R., and Hildenbrand, T.G., 1982, Complete Bouguer gravity anomaly map of the Rio Grande rift, Colorado, New Mexico, and Texas: U.S. Geological Survey Geophysical Investigations Map GP-949, scale 1:1,000,000.

Drewes, Harald, Houser, B.B., Hedlund, D.C., Richter, D.H., Thorman, C.H., and Finnell, T.L., 1985, Geologic map of the Silver City $1^{\circ} \times 2^{\circ}$ quadrangle, New Mexico and Arizona: U.S. Geological Survey Miscellaneous Investigations Series Map I-1310-C, scale 1:250,000.

Duval, J.S., 1983, Composite color images of aerial gamma-ray spectrometric data: Geophysics, v. 48, p. 722-735.

Elston, W.E., 1960, Reconnaissance geologic map of Virden thirty-minute quadrangle: New Mexico State Bureau of Mines and Mineral Resources Geologic Map 15, scale $1: 126,720$.

Ewart, A., 1979, A review of the mineralogy and chemistry of Tertiary-Recent dacitic, latitic, rhyolitic, and related salic volcanic rocks, in Barker, Fred, ed., Trondhjemites, dacites, and related rocks, no. 6 of Developments in Petrology: New York, Elsevier Scientific Publishing Company, p. 13-121.

Gillerman, Elliot, 1964, Mineral deposits of western Grant County, New Mexico: New Mexico State Bureau of Mines and Mineral Resources Bulletin 83, 199 p.

Goudarzi, G.H., comp., 1984, Guide to preparation of mineral survey reports on public lands: U.S. Geological Survey Open-File Report 84-787, 42 p.

Grimes, D.J., and Marranzino, A.P., 1968, Direct-current arc and alternating-current spark emission spectrographic field methods for the semiquantitative analysis of geologic materials: U.S. Geological Survey Circular 591, $6 \mathrm{p}$.

Klein, D.P., 1983, Description of slides showing aeromagnetic and gravity data for regional mineral exploration in Colorado, New Mexico, and Arizona: U.S. Geological Survey Open-File Report 83-703, 13 p.

1987, Aeromagnetic map of the Silver City $1^{\circ} \times 2^{\circ}$ quadrangle, Arizona and New Mexico: U.S. Geological Survey Miscellaneous Investigations Series Map I-1310-D, scale 1:250,000.

Klein, D.P., and Johnson, G.R., 1983, Density, porosity, and magnetic properties of rock specimens from southwestern Arizona: U.S. Geological Survey Open-File Report 83-808, $31 \mathrm{p}$.

Klein, D.P., and Wynn, J.C., 1984, Density, porosity, and magnetic susceptibility of rocks from the Silver City $1^{\circ} \times 2^{\circ}$ quadrangle, Arizona and New Mexico: U.S. Geological Survey Open-File Report 84-17, 11 p.

Muffler, L.J.P., ed., 1979, Assessment of geothermal resources of the United States-1978: U.S. Geological Survey Circular 790, $163 \mathrm{p}$. 
Ratté, J.C., Marvin, R.F., and Naeser, C.W., 1984, Calderas and ash-flow tuffs of the Mogollon Mountains, southwestern New Mexico: Journal of Geophysical Research, v. 89, no. B10, p. 8713-8732.

Richter, D.H., Sharp, W.N., Watts, K.C., Raines, G.L., Houser, B.B., and Klein, D.P., 1986, Maps showing mineral resource assessment of the Silver City $1^{\circ} \times 2^{\circ}$ quadrangle, New Mexico and Arizona: U.S. Geological Survey Miscellaneous Investigations Series Map I-1310-F, scale $1: 250,000$.

Ryan, G.S., 1985, Mineral investigation of part of the Gila Lower Box Wilderness Study Area (NM-030-023), Grant and Hidalgo Counties, New Mexico: U.S. Bureau of Mines Mineral Land Assessment Open File Report $74-85,12$ p.
Ryder, R.T., 1982, Petroleum potential of wilderness lands in New Mexico, in Miller, B.M., ed., Petroleum potential of wilderness lands in the Western United States: U.S. Geological Survey Circular 902, p. I1-I32.

Stacey, J.S., and Hedlund, D.C., 1983, Lead-isotopic compositions of diverse igneous rocks and ore deposits from southwestern New Mexico and their implications for early Proterozoic crustal evolution in western United States: Geological Society of America Bulletin, v. 94, p. $43-57$.

U.S. Bureau of Mines and U.S. Geological Survey, 1980, Principles of a resource/reserve classification for minerals: U.S. Geological Survey Circular 831, 5 p.

Wynn, J.C., 1981, Complete Bouguer gravity anomaly map of the Silver City $1^{\circ} \times 2^{\circ}$ quadrangle, New Mexico-Arizona: U.S. Geological Survey Miscellaneous Investigations Series Map I-1310-A, scale 1:250,000. 

APPENDIX 


\title{
DEFINITION OF LEVELS OF MINERAL RESOURCE POTENTIAL AND CERTAINTY OF ASSESSMENT
}

\author{
Definitions of Mineral Resource Potential
}

LOW mineral resource potential is assigned to areas where geologic, geochemical, and geophysical characteristics define a geologic environment in which the existence of resources is unlikely. This broad category embraces areas with dispersed but insignificantly mineralized rock as well as areas with few or no indications of having been mineralized.

MODERATE mineral resource potential is assigned to areas where geologic, geochemical, and geophysical characteristics indicate a geologic environment favorable for resource occurrence, where interpretations of data indicate a reasonable likelihood of resource accumulation, and (or) where an application of mineral-deposit models indicates favorable ground for the specified type(s) of deposits.

HIGH mineral resource potential is assigned to areas where geologic, geochemical, and geophysical characteristics indicate a geologic environment favorable for resource occurrence, where interpretations of data indicate a high degree of likelihood for resource accumulation, where data support mineral-deposit models indicating presence of resources, and where evidence indicates that mineral concentration has taken place. Assignment of high resource potential to an area requires some positive knowledge that mineral-forming processes have been active in at least part of the area.

UNKNOWN mineral resource potential is assigned to areas where information is inadequate to assign low, moderate, or high levels of resource potential.

NO mineral resource potential is a category reserved for a specific type of resource in a well-defined area.

\section{Levels of Certainty}

\begin{tabular}{|c|c|c|c|}
\hline U/A & $\begin{array}{l}\text { H/B } \\
\text { HIGH POTENTIAL }\end{array}$ & $\begin{array}{l}\text { H/C } \\
\text { HIGH POTENTIAL }\end{array}$ & $\begin{array}{l}\text { H/D } \\
\text { HIGH POTENTIAL }\end{array}$ \\
\hline \multirow{3}{*}{$\begin{array}{l}\text { UNKNOWN } \\
\text { POTENTIAL }\end{array}$} & $\begin{array}{l}\text { M/B } \\
\text { MODERATE POTENTIAL }\end{array}$ & $\begin{array}{l}\text { M/C } \\
\text { MODERATE POTENTIAL }\end{array}$ & $\begin{array}{l}\text { M/D } \\
\text { MODERATE POTENTIAL }\end{array}$ \\
\hline & $L / B$ & $L / C$ & $\begin{array}{l}\text { L/D } \\
\text { LOW POTENTIAL }\end{array}$ \\
\hline & $\begin{array}{l}\text { LOW } \\
\text { POTENTIAL. }\end{array}$ & $\begin{array}{c}\text { LOW } \\
\text { POTENTIAL }\end{array}$ & $\begin{array}{l}\text { N/D } \\
\text { NO POTENTIAL }\end{array}$ \\
\hline A & B & C & $D$ \\
\hline
\end{tabular}

A. Available information is not adequate for determination of the level of mineral resource potential.

B. Available information suggests the level of mineral resource potential.

C. Available information gives a good indication of the level of mineral resource potential.

D. Available information clearly defines the level of mineral resource potential.

\section{Abstracted with minor modifications from:}

Taylor, R. B., and Steven, T. A., 1983, Definition of mineral resource potential: Economic Geology, v. 78 , no. 6, p. $1268-1270$.

Taylor, R. B., Stoneman, R. J., and Marsh, S. P., 1984, An assessment of the mineral resource potential of the San Isabel National Forest, south-central Colorado; U.S. Geological Survey Bulletin 1638, p. $40-42$.

Goudari, G. H., compiler, 1984, Guide to preparation of mineral survey reports on public lands: U.S. Geological Survey Open-File Report 84-0787, p. 7, 8. 


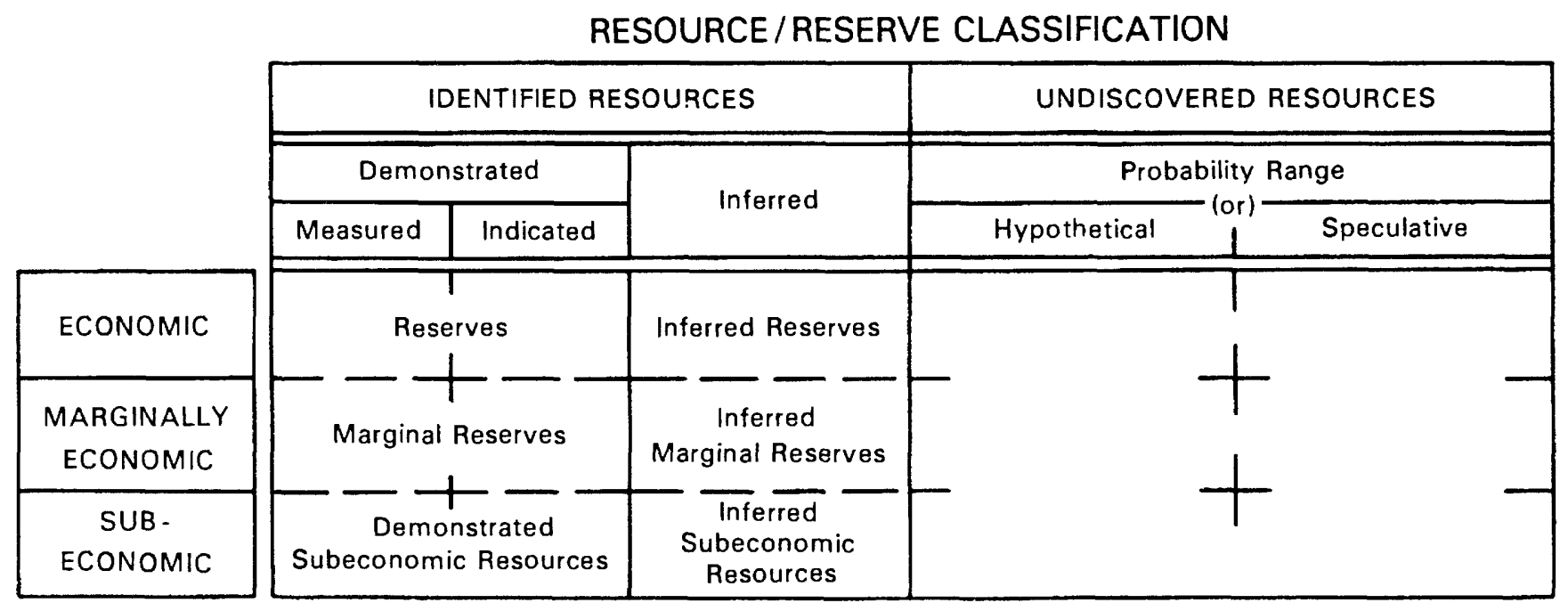

Major elements of mineral resource classification, excluding reserve base and inferred reserve base. Modified from U. S. Bureau of Mines and U. S. Geological Survey, 1980, Principles of a resource/reserve classification for minerals: U. S. Geological Survey Circular 831, p. 5. 
GEOLOGIC TIME CHART

Terms and boundary ages used in this report

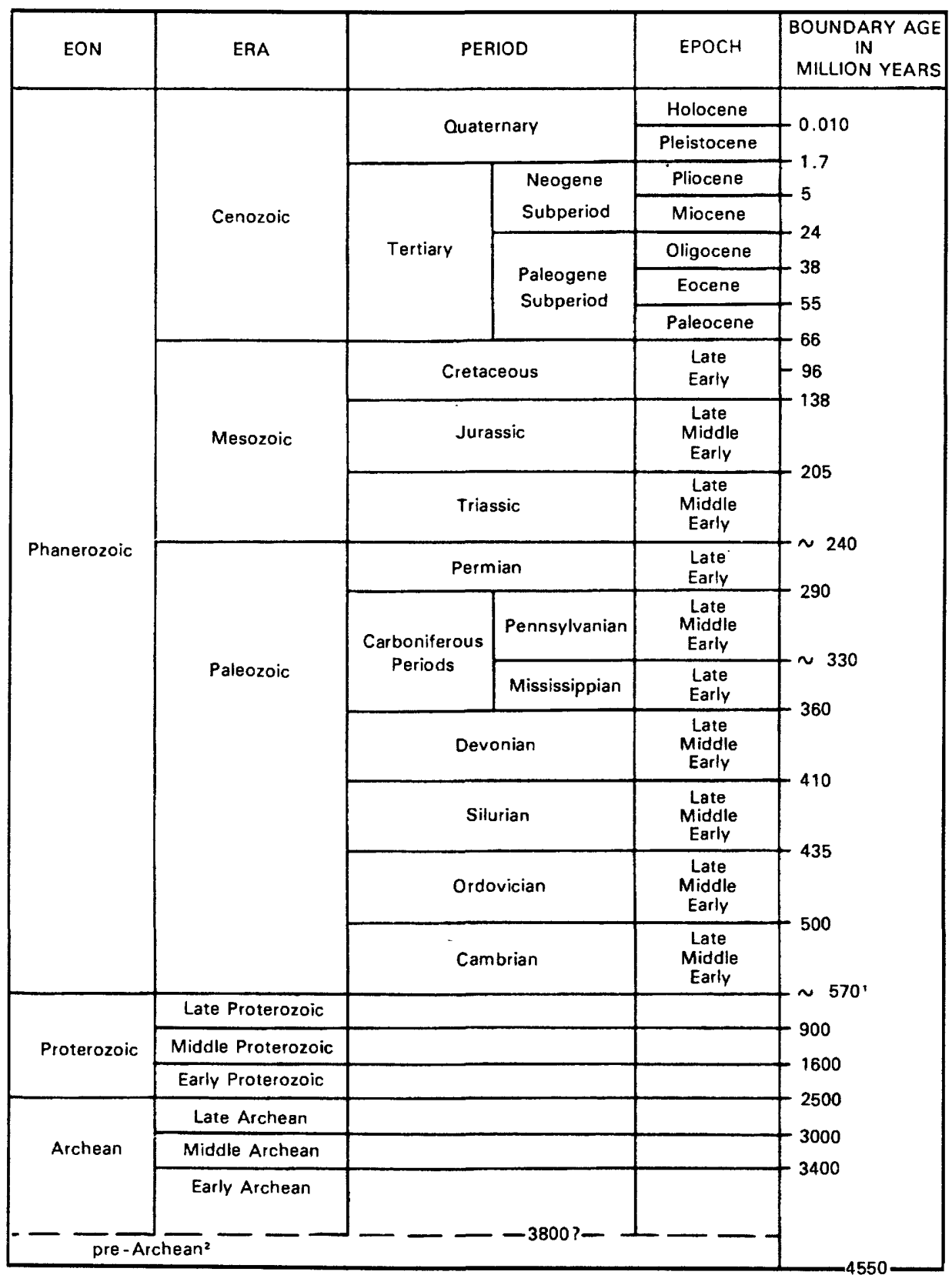

'Rocks older than 570 m.y. also called Precambrian, a time term without specific rank.

2 Informal time term without specific rank. 


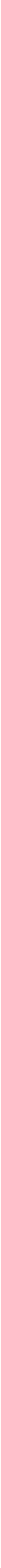




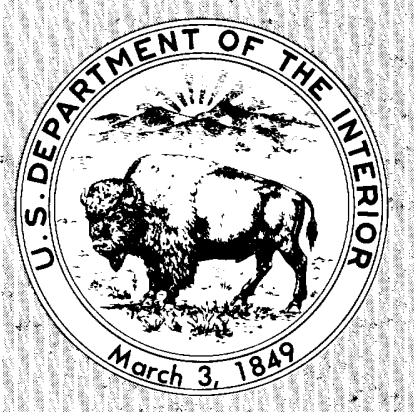

